The Chittagong Univ. J. B. Sci., Vol. 4(1 \&2):63-72, 2009.

\title{
EFFECT OF CADMIUM, CHROMIUM AND MERCURY ON THE LIVER HISTOLOGY OF CLARIAS BATRACHUS L.
}

\author{
SHAWKAT ARA BEGUM ${ }^{1}$, QAMAR BANU AND BAHARUL HOQUE \\ Department of Zoology, University of Chittagong, Chittagong-4331, Bangladesh
}

\begin{abstract}
Effect of cadmium $(\mathrm{Cd})$, chromium $(\mathrm{Cr})$ and mercury $(\mathrm{Hg})$ on liver histology of Clarias batrachus L. was studied after 28 days of exposure to sub lethal concentrations in the said metals under laboratory condition. The common changes in the liver were disruption of hepatic cords, abnormal shape of hepatocytes, pyknotic nuclei, and congestion of blood vessels and sinusoids. Cadmium induced frequent vacuolation in hepatocytes, loss of cell boundary, clumping of nuclei. Atrophied hepatocytes with variegated cytoplasm and necrosed nuclei were specific to $\mathrm{Cr}$ stress, and prominent intercellular spaces around most of the hypertrophied hepatocytes appeared in the liver under $\mathrm{Hg}$ stress.
\end{abstract}

Key words: Heavy metal, pyknotic nuclei, atrophied hepatocytes, variegated cytoplasm.

\section{INTRODUCTION}

The process of accumulation of heavy metals in nature is gradual. But, at present, it has been intensified by different anthropogenic activities like agricultural spray, industrial preservation and manufacturing of different foods and food products, as well as mining. Therefore, water receives these heavy metals and an array of other pollutants through land drainage, industrial effluents, organic wastes, sewage sludge and others (Ching and Hongxiao 1985, Kay et al. 1986). Meanwhile, all kinds of aquatic organisms have become prone to its bad effect through accumulation in different parts of their body, because the natural concentration range for each heavy and/or transition metal is narrow, with excess causing pathological changes (Abbasi and Soni 1984).

Among the heavy metal toxicants i.e., $\mathrm{Cd}, \mathrm{Cr}$ and $\mathrm{Hg}$ have been detected in many waterbodies of Bangladesh in relatively high concentrations (Anonymous 1998, Quraishi and Akhter 2005). Mustafa and Anis (2004) examined the distribution of heavy metals $(\mathrm{Cd}, \mathrm{Cr}, \mathrm{Cu}, \mathrm{Fe}, \mathrm{Mn}, \mathrm{Ni}, \mathrm{Pb}, \mathrm{Zn}$, etc.) in the bed

Corresponding author: 
sediments from Karnaphuli and estuarine zone of the Bay of Bengal and noted their concentrations in the range of 5-7\%. However, the degree of such concentration and their consequent damages may depend on different external and internal factors i.e., the type of body parts, nature of metal, concentration, medium, duration of exposure, etc. Only a very few published reports on the toxic effects of heavy metals on fishes in Bangladesh are available ( Sharif et al. 1993, Holsbeek et al. 1996, Begum and Rakshit 1998, 2000, Begum et al. 2001).

The present work was an attempt to investigate the toxic effect of three heavy metals, such as $\mathrm{Cr}, \mathrm{Cd}$ and $\mathrm{Hg}$ on the liver histology of a freshwater catfish, Clarias batrachus $L$.

\section{MATERIALS AND METHODS}

Fresh and live specimens of $C$. batrachus L. (average length $16 \pm 3 \mathrm{~cm}$ and weight $70 \pm 5 \mathrm{~g}$ ) was bought from Chittagong city market and acclimatized for 7 days in $25 l$ aquarium, containing nonchlorinated tap water. In this condition, the fishes were given oligochaetes, prawn and small pieces of Harpodon nehereus as food once in a day and the contained water was changed at $24 \mathrm{~h}$ interval. Following it, 15 fish specimens in each $25 l$ aquarium were exposed to each sub lethal conc. of heavy metals $(\mathrm{Cd}-9 \mathrm{ppm}, \mathrm{Cr}-12 \mathrm{ppm}$ and $\mathrm{Hg}-0.3$ ppm) for 28 days along with a control without heavy metal. Test fishes in the aquaria were fed once a day with a change of solution after each feeding.

Humason (1961) was followed for histopathological study. At the end of the exposure period, liver from the metal exposed as well as control fishes were isolated, cleaned with physiological saline solution, cut into pieces and fixed in freshly prepared Bouin's fixative. After 24 hours, tissues were transferred to $70 \%$ alcohol for preservation. For histological slides preparation, tissues were dehydrated in graded alcohol, cleared in benzene and embedded in paraffin. Thin sections $(3-5 \mu)$ were cut by a rotary microtome, double stained by eosinhaematoxylin, mounted with DPX for examination under microscope. Photomicrographs were taken by Ricoh 35 mm SLR camera.

\section{RESULTS AND DISCUSSION}

In control, liver of $C$. batrachus comprised numerous polyhedral hepatocytes each with a central rounded nucleus containing a prominent nucleolus. The cytoplasm of the hepatocytes was uniformly granular. The hepatocytes were arranged in tubules or cords of cells. Sinusoids were irregularly distributed between the tubules or cords of hepatocytes. Numerous blood vessels, 
portal veins and blood capillaries were scattered in the hepatic parenchyma (Plate $1)$.

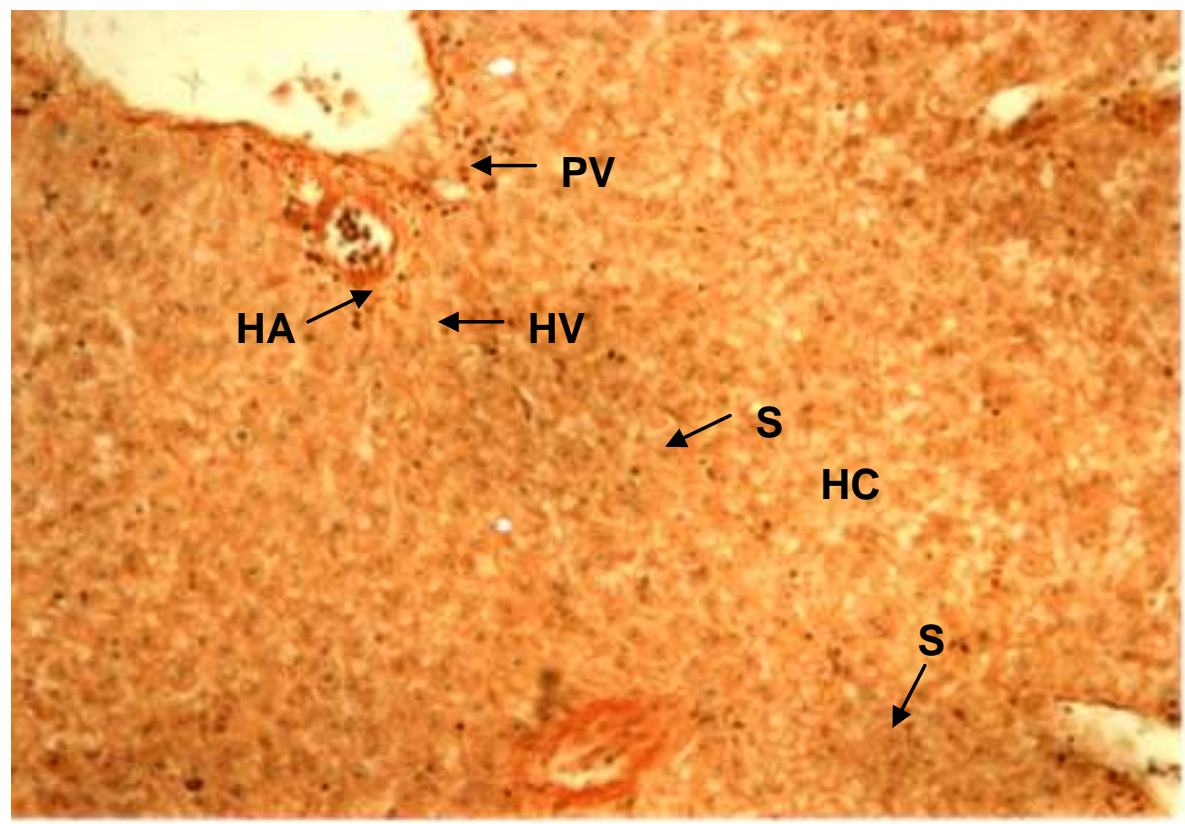

PLATE 1. PHOTOMICROGRAPH OF THE SECTION OF LIVER OF CONTROL SPECIMEN OF CLARIAS BATRACHUS SHOWING HEPATOCYTES (HC) WITH UNIFORMLY GRANULAR CYTOPLASM, PORTAL VEIN (PV), HEPATIC ARTERY (HA), HEPATIC VEIN (HV) AND SINUSOIDS (S). H\&E 10×40.

Whereas, under treatment, hepatic lesions were noted due to expose in heavy metals, like $\mathrm{Cd}, \mathrm{Cr}$ and $\mathrm{Hg}$. These lesions include degeneration of hepatocytes, hypertrophied hepatocytes with pyknotic nuclei and clear cytoplasm, vacuolation of hepatocytes, loss of the normal shape of hepatocytes, displacement of nuclei, disruption of hepatic cords, rupture in the tissue, necrosis, and congestion of blood vessels and sinusoids (Plates 2,3,4). Similar degenerative changes in the liver tissues of fishes exposed to different toxicants, including heavy metals, were recorded in several earlier studies (Victor et al. 1985, Bhattacharya et al. 1986, Gupta and Rajbanshi 1988, Benedetti et al. 1989, Wester and Canton 1992, Wajsbrot et al. 1993, Schramm et al. 1998, Sharma et al. 2001). 


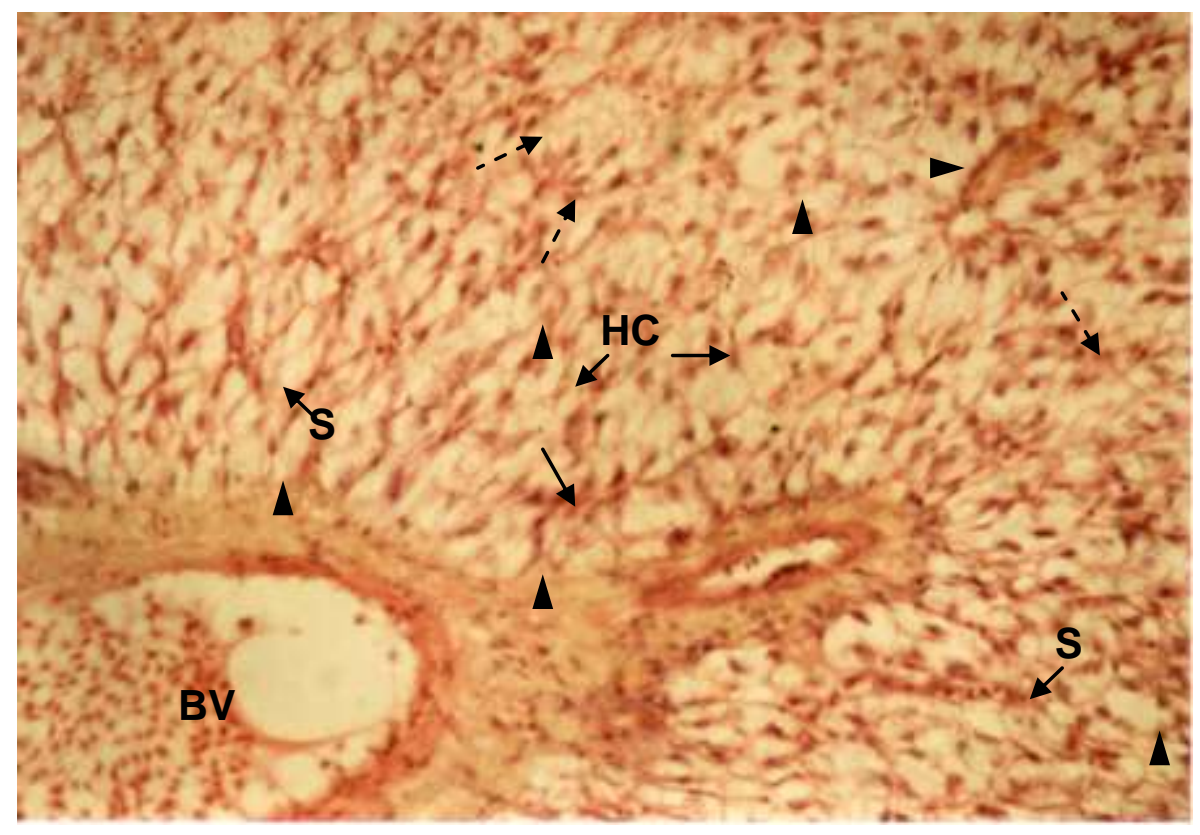

PLATE 2. PHOTOMICROGRAPH OF THE SECTION OF LIVER OF CD-EXPOSED CLARIAS BATRACHUS SHOWING DISARRANGEMENT OF HEPATIC CORDS, DEFORMED AND ATROPHIED HEPATOCYTES (HC) WITH SHRUNKEN, DISPLACED NUCLEI, AGGREGATION OF NUCLEI (BROKEN ARROW) DUE TO LOSS OF CELL BOUNDARIES, VACUOLATION OF HEPATOCYTES (ARROW HEAD), CONGESTION OF BLOOD IN THE BLOOD VESSELS (BV) AND SINUSOIDS (S). H\&E 10×40. 


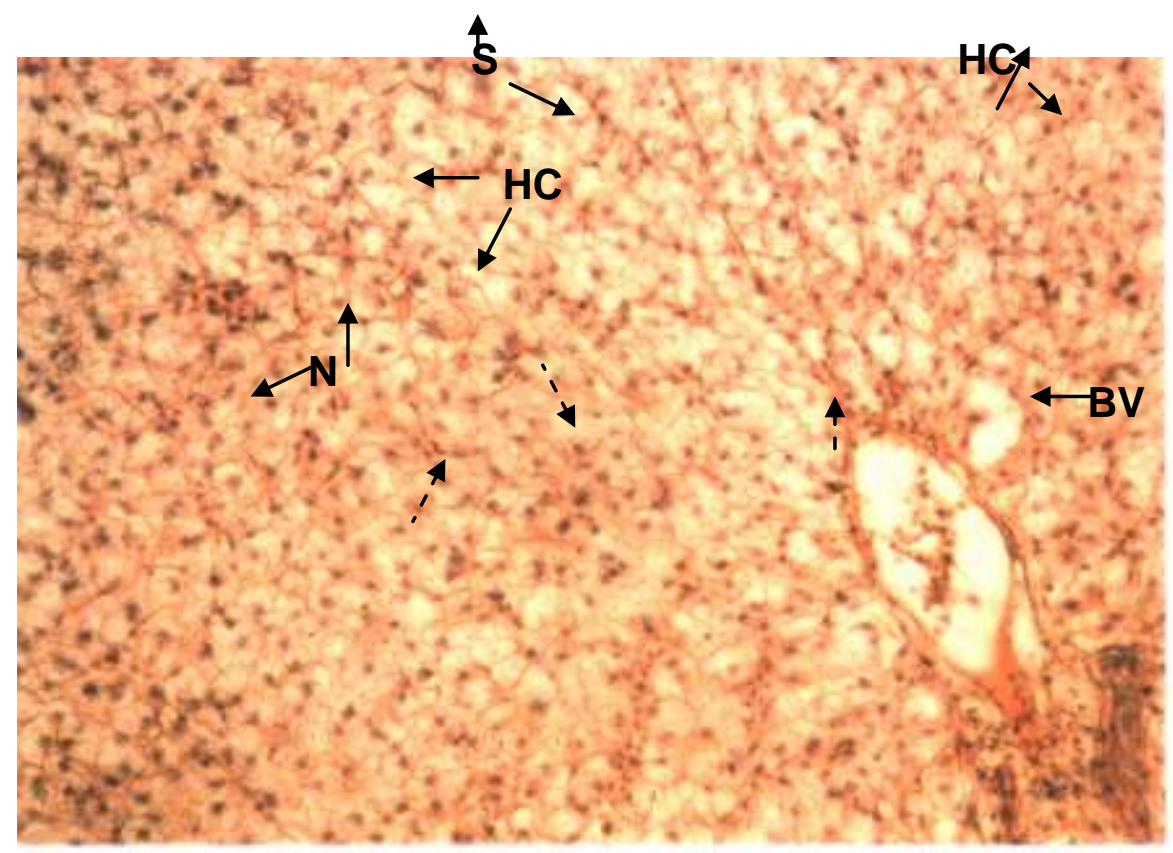

PLATE 3. PHOTOMICROGRAPH OF THE SECTION OF LIVER OF CR-EXPOSED CLARIAS BATRACHUS SHOWING LOSS OF NORMAL PALLISADE ARRANGEMENT OF HEPATIC PARENCHYMA, DESHAPED HEPATOCYTES (HC) WITH VARIEGATED CYTOPLASM AND PYKNOTIC, ATROPHIED AND NECROSED NUCLEI (N); VACUOLATION IN HEPATOCYTES (BROKEN ARROW); HYPEREMIC SINUSOIDS (S) AND BLOOD VESSELS (BV). H\&E 10×40. 


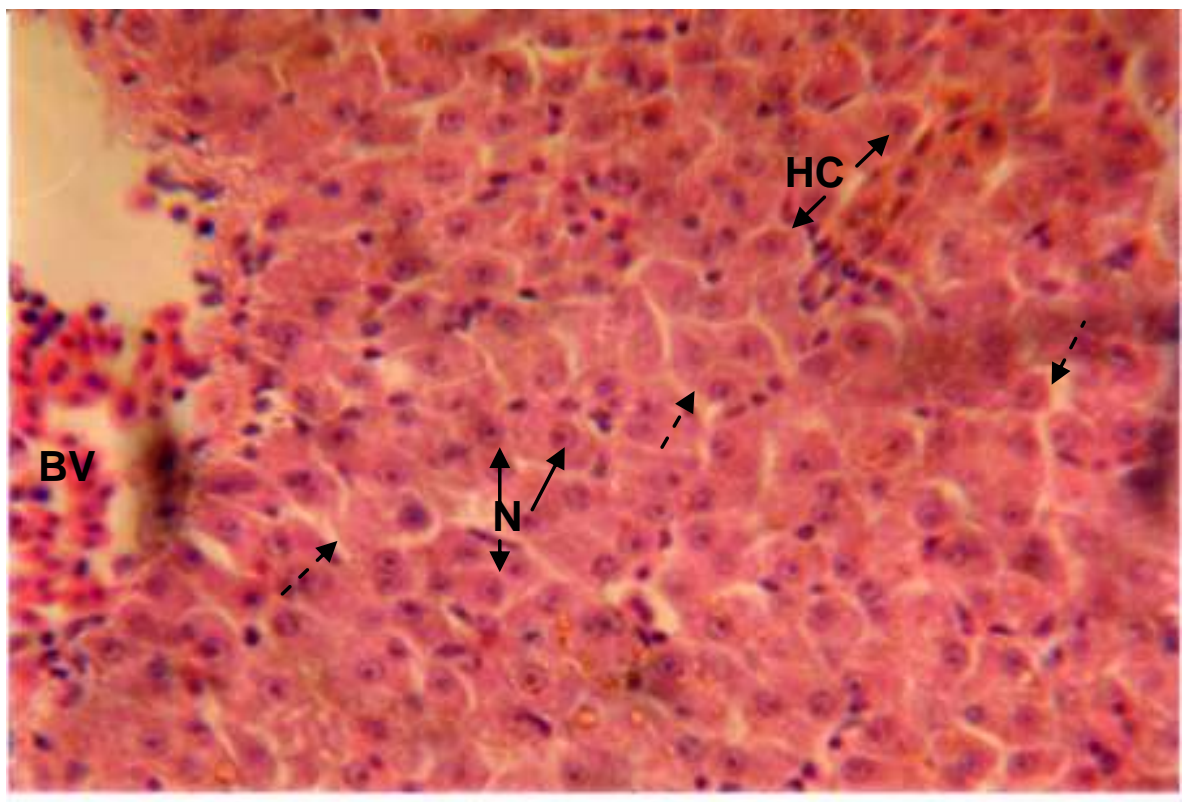

Plate 4. Photomicrograph of the section of liver of Hg-exposed Clarias batrachus showing hypertrophied, deshaped hepatocytes $(\mathrm{HC})$ with swollen pyknotic nuclei $(\mathrm{N})$ and prominent intercellular spaces (broken arrow) around the hepatocytes, and hyperemic blood vessels (BV). H\&E $10 \times 4$

Specific effects in hepatic cells because of accumulation of the respective heavy metals suggest that the $\mathrm{Cd}$ atrophied hepatocytes with shrunken pyknotic nuclei, surface irregularity and sometimes loss of cell boundaries (Plates 2). These kind of atrophied hepatocytes with shrunken nuclei were also reported by Wajsbrot et al. (1993) in ammonia treated Juveniles gilthead sea bream, Sparus aurata. Sultan and Khan (1981) observed much damaged hepatocytes with shrunken nuclei in the liver of Molienesia species, while exposed to $100 \mu \mathrm{g} l^{-1}$ copper sulphate for 25 days. Thophon et al. (2004) in an ultra structural investigation of the $\mathrm{Cd}$ exposed fish, Lates calcarifer, also reported swelling and lysis of hepatocytes. Wester and Canton (1992) reported hepatocytes containing swollen vesicular nuclei with prominent nucleoli in guppy, Poecilia reticulata, exposed to methyl mercury and suggested such symptoms as indicative of increased cellular activity e.g., protein synthesis. This was probably associated with detoxification and metabolic process of toxicants in the liver that would ultimately lead to cell death (Stoker et al. 1985). 
In case of $\mathrm{Hg}$ exposed fish of the present study, liver showed hypertrophied hepatocytes with pyknotic, swollen or displaced nuclei (Plates 4). Even, a specific pathological response was noted in the liver of the test fish on exposure to mercury solution. It was the development of distinct intercellular spaces around most of the hepatocytes. Konar (1970) in an experiment with rui, Labeo rohita, exposed to sub lethal levels of heptachlor observed, to some extent, similar damages and suggested that intercellular spaces were formed due to the rupture of swollen degenerated hepatic cells. Beside this, other changes such as swollen hepatocytes, loss of normal shape, pyknotic swollen nuclei, hyperemic blood vessels, etc. were also seen in the $\mathrm{Hg}$-treated fishes.

The hepatocytes with prominent variegated cytoplasm, atrophied and necrosed nuclei, and sinusoids congested with blood were the significant pathological symptoms in liver tissue of the test fish in response to $\mathrm{Cr}$ stress (Plate 3 ). Besides, disruption of normal arrangement of hepatic cords, congestion in blood vessels and sinusoids, variegated cytoplasm with heterogenous staining or clear cytoplasm of the hepatic cells due to loss of affinity for stain, etc., were noted in test fish on exposures to all three heavy metals (Plates 2, 3, 4). Similar histopathological symptoms were reported by a good number of workers in liver of different animal species exposed to toxicants (Smith and Piper 1975, Bhattacharya et al. 1986, Wester and Canton 1992 and Wajsbrot et al. 1993). Couch (1975) explained liver damage as a result of asphyxia or tissue hypoxia due to secondary lamellae damage of the fish gill. Stoker et al. (1985), on the other hand, suggested that liver damage was due to chemical action and not as a result of mere hypoxia. The latter observation seems to be more applicable for the present findings. While working with rainbow trout, Oncorhynchus mykiss, Nigrelli and Jakowska (1961) and Wood and Larson (1961) observed hepatocyte vacuolation under light microscopy and interpreted it as evidence of dipodic degeneration. According to Hinton and Lauren (1990) the true dipodic degeneration is a usual pathological response with exposure of fish to certain toxins.

\section{REFERENCES}

ABBASI, S. A. AND SONI, R. 1984. Toxicity of lower than permissible levels of chromium (VI) to freshwater teleost Nuris denricus. Environ. Pollut. Ser. A. 36: 75-82. 
ANONYMOUS. 1998. Industrialization and industrial pollution. In: Bangladesh Environment: Facing the 21st century. (Ed., Gain, P.). SEHD, Dhaka. pp.165-185.

BEGUM, S. A., KHANAM, F. AND HOQUE, B. 2001. Effects of chromium on histological structures of different organs of Clarias gariepinus (Burchel). The Chittagong Univ. J. Sci. 25(1): 1-10.

BEGUM, S. A. AND RAKSHIT, D. 1998. Effects of heavy metals on behaviour, mortality and liver ATPase activity of Oreochromis mossambicus (Peters). The Chittagong Univ. J. Sci. 21(1): 5-12.

BEGUM, S. A. AND RAKSHIT, D. 2000. Effect of three heavy metals on the behaviour, mortality and ATPase activity of Channa punctatus (Bloch). The Chittagong Univ. J. Sci. 24(1): 31-38.

BENEDETTI, I., ALBANO, A. G. AND MOLA, L. 1989. Histomorphological changes in some organs of the brown bullhead, Ictalurus nebulosus Le Sueur,following short- and long- term exposure to copper. J. Fish Biol. 34(2): 273-280.

BHATTACHARYA, T., RAY, A. K. AND BHATTACHARYA, S. 1986. Histopathological lesions in the hepatopancreas of Channa punctatus (Bloch) exposed to mixtures of mercuric chloride and phenol and a factory effluent. Matsya. 11: 1- 4.

CHING, I. L. AND HONGXIAO, T. 1985. Chemical studies of aquatic pollution by heavy metals in China. In: Environmental inorganic chemistry. VCH Pub. Inc.

COUCH, J. A. 1975. Histopathological effects of pesticides and related chemicals on the livers of fishes. In: The pathology of fishes. (Ed.,Ribelin, W.E. and Migaki, G.), Madison: University of Wisconsin Press. pp. 559584.

GUPTA, A. K. AND RAJBANSHI, V. K. 1988. Acute toxicity to cadmium to Channa punctatus (Bloch). Acta hydrochim. hydrobiol. 16(5): 525535.

HINTON, D. E. AND LAUREN, D. J. 1990. Liver structural alterations accompanying chronic toxicity in fishes: potential biomarkers of exposure. In: Biomarkers of Environmental Contaminations (Ed., McCarthy, J. F. and Shugart, L. F.). Lewis Publishers, Florida. pp. 1757.

HOLSBEEK, L., DAS, H. K. AND JOIRIS, C. R. 1996. Mercury in human hair and relation to fish consumption in Bangladesh. Sci. Total Environ. 186:181-188. 
HUMASON, L. G.1961. Animal tissue technique. $2^{\text {nd }}$ ed. W. H. Freeman and Company. Sunfrancisco, U.S.A.

KAY, J., THOMAS, D. G., BROWN, H. V., CRYER, A., SHURBEN, D., SOLBE, J. F., DE, L. G. AND GARSNEY, J. S. 1986.Cadmium accumulation and protein binding patterns in tissues of the rainbow trout (Salmo gairdneri). Environ. Health Perspect. 65:133-139.

KONAR, S. K. 1970. Some effects of sub-lethal levels of heptachlor on Labeo rohita. J. Inland Fish. Soc. India. 2: 50- 54.

MUSTAFA, A. I. AND ANIS, W. 2004. Heavy metal distribution in the coastal and estuarine zone sediments at the outfall of the Karnafully River. $J$. Asiat. Soc. Bangladesh, Sci. 30(2): 87-94.

NIGRELLI, R. E. AND JAKOWSKA, S. 1961. Fatty degeneration regenerative hyperplasia and neoplasia in the livers of rainbow trout, Salmo gairdneri. Zoologica. 46: 49-61.

QURAISHI, S. B. AND AKHTER, S. 2005. Study of concentration of some toxic and essential elements in marine water, sediment and their impact on marine biota. J. Bangladesh Acad. Sci. 29(2): 163-171.

SCHRAMM, M., MUELLER, E. AND TRIEBSKORON, R. 1998. Brown trout (Salmo trutta f. Fario) liver ultrastructure as a biomarker for assessment of small stream pollution. Biomarkers. 3(2): 93-108.

SHARIF, A. K. M., ALAMGIR, M., MUSTAFA, A. I., HOSSAIN, M. A. AND AMIN, M. N. 1993. Trace element concentrations in ten species of freshwater fish of Bangladesh. Sci. Total Environ. 138: 117-126.

SHARMA, R. R., PANDEY, A. K. AND SHUKLA, G. R. 2001. Histopathological alterations in fish induced by pesticides toxicity. Aquacult. 2(1): 31-43.

SMITH, C. E. AND PIPER, R. G. 1975. Lessions associated with chronic exposure to ammonia. In: The Pathology of Fishes (W. E. Ribelin and G. Migaki, eds.) Madison.University of Wisconsin Press, pp. 497-514.

STOKER, P. W., LARSEN, J. R., BOOTH, G. M. AND LEE, M. L. 1985. Pathology of gill and liver tissues from two genera of fishes exposed to two coal- derived materials. J. Fish Biol. 27: 31-46.

SULTAN, S AND KHAN, S.M. 1981. Histopathological lesions induced by copper sulphate in hepatopancreas of Mollienesia sp. Indian J. Fish. 28(1 and 2): 274-277

THOPHON, S., POKETHITIYOOK, P., CHALERMWAT, K., UPATHAM, E. S. AND SAHAPHONG, S. 2004. Ultrastructural alterations in the liver and kidney of white sea bass, Lates calcarifer, in acute and subchronic cadmium exposure. Environ. Toxicol. 319(1): 11-19. 
VICTOR, B., MAHALINGAM, S. AND SAROJINI, R. 1985. Cytopathological effects of cadmium on the freshwater prawn Macrobrachium idae. Indian J. Fish. 32(4):82-86.

WAJSBROT, N., GASETH, A., DIAMONT,A. AND POPPER, D. M. 1993. Chronic toxicity of ammonia to juvenile gilthead seabream Sparus arrata and related histopathological effects. J.Fish Biol., 42:321-328.

WALSH, A. H. AND RIBELIN, W. E. 1975. The pathology of pesticide poisoning. In:The pathology of Fishes. RIBELIN, W. E. and MIGAKI, G.(eds.);Madison, University Press of Wisconsin Press. 515-546pp.

WESTER, P. W. AND CANTON, H. H. 1992. Histopathological effects in Poecilia reticulata (Guppy) exposed to methyl mercury chloride. Toxicologic pathology. 20 (1): 81-92.

WOOD, E. M. AND LARSON, C. P. 1961. Hepatic carcinoma in rainbow trout. Arch. Pathol. 71:471-479.

Manuscript received on 25.5.09; Accepted on 24.10. 09

The Chittagong University Journal of Biological Sciences, Vol.4 ( 1 \& 2): Page No : 63-72 